\title{
Jack Treynor and the Birth of the Quants
}

By Mark Harrison, CFA

Jack L. Treynor, who died this past May, was a key member of a tiny group of theorists from which the efficient market hypothesis (EMH), the capital asset pricing model (CAPM), and the random walk hypothesis emerged in the 1960s. In a world without Jack Treynor, mass casino psychology and fund manager guru-worship might rule, unchallenged by any metrics other than crude popularity and marketing spend.

Instead, the field of quantitative investment was born, a feat due in no small part to Treynor's battle against prejudice and misunderstanding about the use of mathematics in investment.

\section{TOWARD A THEORY OF MARKET RISK AND BETA}

Treynor's early theoretical advance was in defining the spread, or risk premium, between anticipated investor returns over the risk-free rate and showing how critical that measure was to solving the portfolio formation problem.

In Treynor's model, outlined in an unpublished 1961 paper, "Toward a Theory of Market Value of Risky Assets," where (to the eternal confusion of practitioners) investors had unlimited borrowing and capacity to short, the anticipated excess return over the risk-free rate per share "is proportional to the covariance of the investment with the total value of all the investments in the market."

Although the term "beta" didn't arise until later, Treynor had nailed a theory of market value that incorporates risk premiums and helps objectively define and calibrate investment risk. His unpublished 1961 paper circulated among William F. Sharpe and other theorists, yet controversially, it was Sharpe, not Treynor, who was awarded the Nobel Prize nearly 30 years later.

Today, not just the market factor but a zoo of factors exist-quantitative investors alone track over 400 factors. Diverse active and passive forms of quantitative

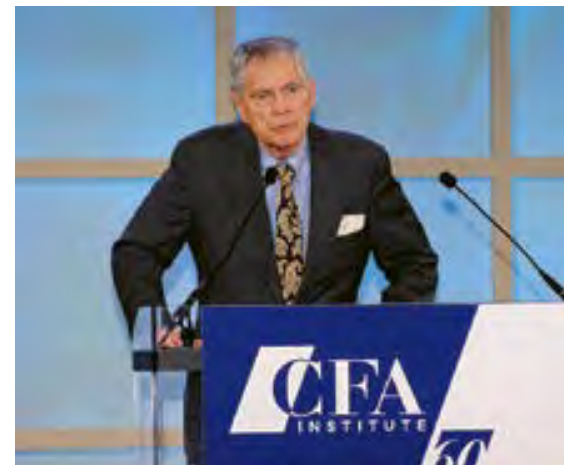

investment increasingly dominate the investment scene, with Morningstar reporting $40 \%$ of US mutual funds are now passively managed.

\section{BRINGING OBJECTIVITY TO PERFORMANCE MEASUREMENT}

When the financial crisis came along, many found easy scapegoats in the Chicago school of EMH theorists and financial models. Although Treynor was also a key theorist responsible for the CAPM, however, his perspective was always about how quantitative innovation could directly help investment practitioners and corporates. In that endeavor, he made as many enemies as friends.

By the mid-1960s, Treynor was working at Arthur D. Little, a consulting firm, on a project to determine why the Yale endowment's managers seemed so unimpressive by the prevailing returnsbased yardsticks. In a tale that will be depressingly familiar to many college endowments, alumni were aggressively pushing various fashionable fund managers, all claiming stellar performance:

"The pro they had in mind was ... Jerry Tsai," said Treynor in a June 2008 interview with the American Finance Association. "So they gave me his record, and I applied my method. It turned out he had a beta of two, and they were looking at a period of time when the market had finally decided we weren't actually going back into the Great Depression after the Second World War. When you allowed for the fact that Jerry had a beta of two, there wasn't anything left for Jerry's alpha. That didn't make me terribly popular."

Characteristically, Treynor chose to publish his innovative method in several articles for the Harvard Business Review, a publication widely read by investment practitioners. Generations of CFA Program examination candidates will be familiar with the Treynor ratio, which objectively measures the performance of funds adjusted for risk instead of just returns. The Treynor ratio divides excess returns into market beta and so is easily confused with the Sharpe ratio, which uses standard deviation in the denominator. In the same way that the Sharpe ratio measures excess return per unit of total risk (standard deviation), the Treynor ratio measures excess return per unit of market risk (undiversifiable risk) and actually works best with a portfolio that is already quite diversified.

\section{A LIFETIME OF IDEAS}

Treynor will forever be associated with the emergence of CAPM and, of course, his famous ratio, but the story doesn't end there. Between stints at Arthur D. Little and Merrill Lynch working with Donald Regan - later secretary of the Treasury under President Ronald Reagan-further ingenious papers followed. Of particular note was one cowritten with Fischer Black that examined how to use security analysis to improve portfolio selection. Treynor's topics ranged freely from the macroeconomic sphere (growth theory, inflation, money, and trade) to microeconomics (monopoly and competition) to accounting.

Combining the intellectually novel with the practical application of new ideas was a running theme of Treynor's work. For example, applied research on pension finance and municipal bonds was influenced by the latest optionspricing theory being developed by Fischer Black and Myron Scholes. 


\section{A DIFFICULT BIRTH FOR QUANT}

Treynor often talked of "slow ideas" that are of little interest to the average investor. In one Financial Analysts Journal article, "Long-Term Investing," Treynor wrote: "When one talks about market efficiency, it is important to distinguish between ideas whose implications are obvious and consequently travel quickly and ideas that require reflection, judgment, and special expertise for their evaluation and consequently travel slowly." This notion seems just as apt for the progress of his own ideas.

In another Journal piece, "The Only Game in Town" (written under the pseudonym Walter Bagehot), Treynor evaluated the economics of market making by asking why investors persist in trading despite their dismal long-run trading record and why trading against the public isn't consistently profitable.

Speaking at a CFA Institute conference in Toronto in 1992, Treynor told investors the most meaningful measure of performance for active portfolios is not total return but the increment in return that results from trading. For Treynor, a crucial element in this equation is "invisible" transaction costs-those related to exchanging perceived price advantages

\section{KEEP GOING}

"In Memoriam: The Collected Works of Jack Treynor": http://cfa.is/29hVPv3

"Measures of Risk-Adjusted Return: Let's Not Forget Treynor and Jensen," Investment Performance Measurement Feature Articles (Vol. 2011, No. 1) [www.cfapubs.org]

"Long-Term Investing," Financial Analysts Journal (May/June 1976) [www.cfapubs.org]

"The Only Game in Town," Financial Analysts Journal (March/April 1971) [www.cfapubs.org]

"Types and Motivations of Market Participants," AIMR Conference Proceedings (June 1993, Issue 3 ) [www.cfapubs.org] for perceived time advantages.

Treynor's wide-ranging contributions at the Journal and later at Q Group and elsewhere helped to more widely circulate new ideas about the use of quantitative techniques among skeptical investment professionals. Treynor served as editor of the Journal from 1969 to 1981 and was a regular contributor until the mid-1990s.

The greatest barrier to the acceptance of novel concepts or techniques (especially those involving mathematical language that many find tedious) is human prejudice. The gradual incorporation of innovations such as quantitative techniques into the investment profession, even if they in hindsight appear a linear triumph, was hindered by many obstacles that Jack L. Treynor did much to overcome.

Mark Harrison, CFA, is director of publications at CFA Institute. This article was originally posted on Enterprising Investor (blogs.cfainstitute. org/investor).

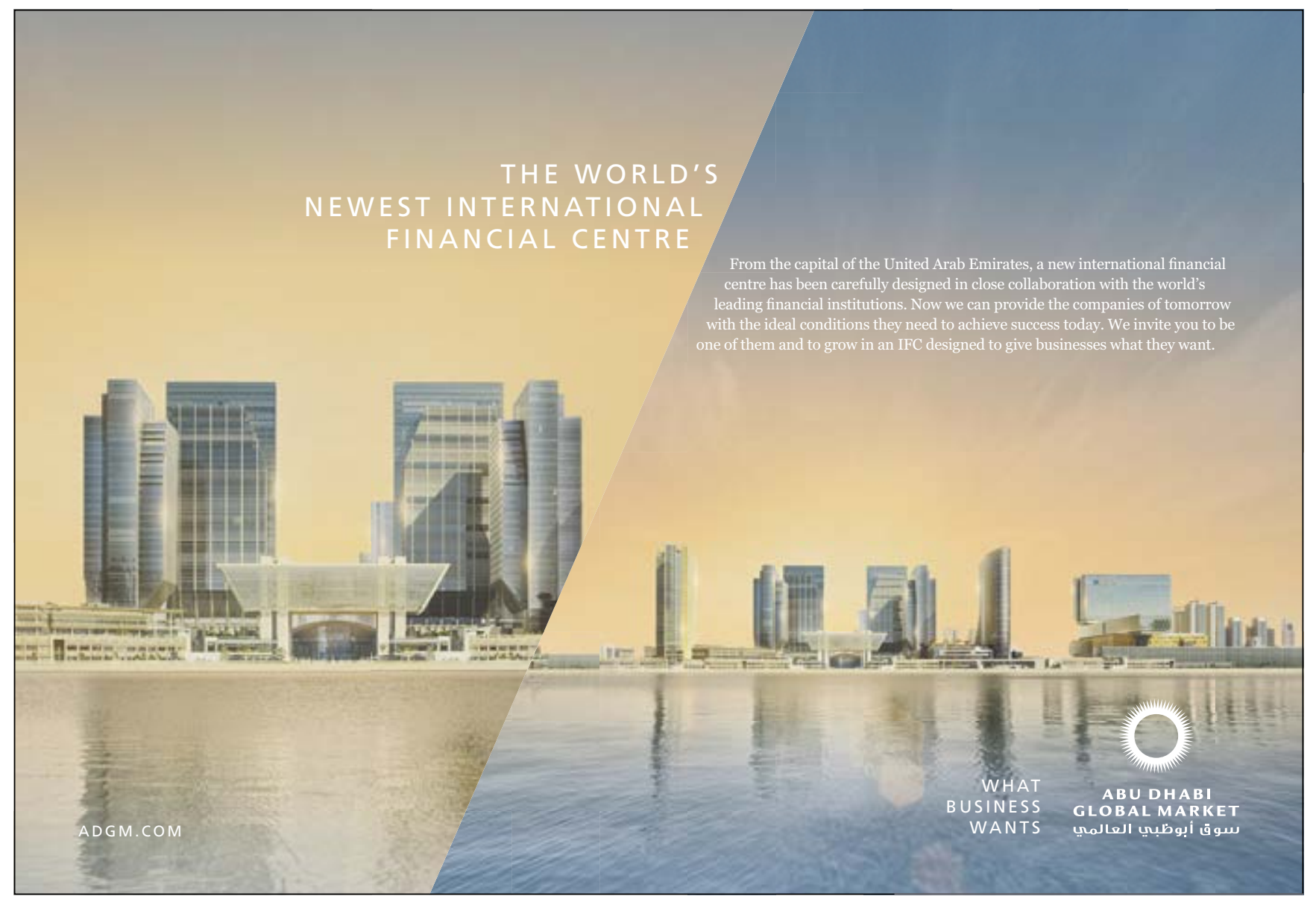

